\title{
Quantification of $\beta$-ecdysone in differents parts of Pfaffia glomerata by HPLC
}

\author{
Lara Z. Serra, Daniele F. Felipe, Diógenes A. G. Cortez*
}

Laboratório de Pesquisa em Produtos Naturais e Biotecnologia, Universidade Estadual de Maringá, Brazil.

\begin{abstract}
Pfaffia glomerata (Spreng.) Pedersen, Amaranthaceae, is widely distributed in Brazil. Roots are considered as the world's greatest supplier and $\beta$-ecdysone is the most important compound extracted from roots of Pfaffia glomerata. So, the aim this study was analyze the presence of $\beta$-ecdysone in the inflorescences and stems and compared with the content from roots of Pfaffia glomerata and determine the best extractive method of $\beta$-ecdysone this plant. The crude extracts were obtained by Soxhlet method, reflux, maceration, percolation and turbolyse. Compound extracts were quantified by High Performance Liquid Chromatography (HPLC). The analysis were carried out a Phenomenex Column C18, $5 \mu \mathrm{m}, 250 \times 4,6 \mathrm{~mm}$, maintened at $30^{\circ} \mathrm{C}$, gradient system using as mobile phase a mixture of methanol and water, flow rate $1,0 \mathrm{~mL}$ and detection at 245 $\mathrm{nm}$. Results showed Soxhlet method with ethanol:water $(90: 10 \mathrm{v} / \mathrm{v})$ presented the higher concentration of $\beta$-ecdysone in $P$. glomerata and inflorescences showed higher amount of this active substance $(3,06 \%)$, compared with stems $(2,37 \%)$ and roots $(1,63 \%)$, showing that the inflorescences and plant stems may also be used as a rich source of $\beta$-ecdysone.
\end{abstract}

Received 8 May 2012

Accepted 20 Jul 2012

Available online 20 Sep 2012

Keywords: Pfaffia glomerata $\beta$-ecdysone extraction HPLC

ISSN 0102-695X http://dx.doi.org/10.1590/S0102$695 \times 2012005000114$

\section{Introduction}

Species of the genus Pfaffia, Amaranthaceae, are marketed in Brazil as substitutes for Panax spp. Because of the similar morphology of their roots to those of ginseng, these species are popularly known as "Brazilian ginseng", and are used as a tonic, and to treat gastric disturbances and rheumatism (Oliveira et al., 1998).

The genus Pfaffia comprises about ninety species distributed through Central and South America, twenty-seven of which are known from Brazil (Taniguchi et al., 1997), is considered as the world's greatest supplier of $P$. glomerata roots.

The Pfaffia glomerata (Spreng.) Pedersen roots extracts possess activity gastro-protector (Otofuji, 2005), anti-inflamatory, analgesic (Neto et al., 2005), antioxidant (Souza et al, 2005), anti-hiperglicemic (Sanches et al., 2001), tonic, aphrodisiac (Marques et al., 2004, Freitas et al., 2004), antireumathics (Nicoloso et al., 1999), antitumoral and antidiabetics properties, and also as food supplement, among other indications (Montanari Junior, 2005). It also aids the protection and disturbances in the gastric mucous membrane (Freitas et al., 2004), purification of the blood and the hormonal and sexual functions regulation (Guerreiro, 2006).

Among active ingredients contained in this plant, the steroid $\beta$-ecdysone is the most important compound extracted from roots (Gomes et al., 2010).

A study of the seasonal variation of $\beta$-ecdysone contents, using different cessions of Pfaffia glomerata collected along the Paraná, Ivaí, and Paranapanema rivers suggested that twelve months after planting is the most appropriate time to harvest Pfaffia roots (Correa Junior et al., 2008).

Shiobara et al. (1993), identified glomeric acid (triterpenoid) and pfameric acid (nortriterpenoid), $\beta$-ecdysone, rubrosterone, oleanolic acid and $\beta$-glucopyranosyl oleanolate in Pfaffia glomerata (Spreng.) Pederson. A recent study, confirmed the presence of significant amounts of $\beta$-ecdysone in theis roots of this plant (Freitas et al., 2004). According to Cortez et al. (1998), $\beta$-ecdysone is the most important steroid employed in cosmetic formulations.

This compound acts by increasing cellular cohesion, regulating and normalizing keratinocyte differentiation; it lends the skin a smoother and smoother appearance and restores the protective and water-barrier functions of skin, preventing excessive water loss and forming an effective hydractant (Cortez et al., 1998)

The aim of present study was evaluate the presence and quantification of $\beta$-ecdysone in differents parts of Pfaffia glomerata and determine the best method to extract $\beta$-ecdysone from $P$. glomerata. 


\section{Materials and Methods}

\section{Plant material}

Pfaffia glomerata (Spreng.) Pedersen, Amaranthaceae, was collected on Querência do NorteParaná, Brazil, in April 2010. The plant was collected and identified by Prof. Dra. Maria Salete Marchioretto. A voucher specimen (PACA 107100) is deposited at the Herbarium PACA - Universidade do Vale do Rio dos Sinos-RS, Brazil. The plant was dried in a circulating air stove, at $45^{\circ} \mathrm{C}$, triturated in a knife mill (Usi-ram ${ }^{\circledR}$ ) and stoked.

\section{Crude extracts}

Crude extract were obtained from five methods of extraction: maceration (Neto et al., 2005) percolation (Farmacopéia Brasileira, 1988) turbolyse (De-Paris et al., 2000) reflux (Gosmann et al., 2003) and Soxhlet method (Flores et al., 2009) using three different mixture of solvents, ethanol:water $(90: 10 \mathrm{v} / \mathrm{v}),(80: 20 \mathrm{v} / \mathrm{v})$ and $(50: 50 \mathrm{v} / \mathrm{v})$. For the preparation of extracts, used $10 \mathrm{~g}$ of $P$. glomerata triturated and the extract was filtered, the organic solvent was removed under "vacuum" and lyophilized. The results represented the average of three determinations. The data were compared by ANOVA followed Tukey's test $(\alpha=0.05)$. Stems and inflorescences of the plant were also extracted for detection of the presence of $\beta$-ecdysone in these parts.

\section{HPLC analysis}

\section{Reagents and chemicals}

Methanol (HPLC grade from Merck) and ultrapure water (Milli-Q system, Millipore) were used for the mobile phase preparation. Methanol (HPLC grade from Merck) was used for samples preparation $\beta$-ecdysone $\left(\right.$ Chromadex $\left.^{\circledR}\right)$ was purchased commercially used as a standard.

\section{Sample preparation}

To obtain the stock solutions, $\beta$-ecdysone was prepared in methanol at a concentration of $1000 \mu \mathrm{g} / \mathrm{mL}$. Also, the roots, stems, and inflorescences of $P$. glomerata crude extracts were prepared in methanol at a concentration of $3000 \mu \mathrm{g} / \mathrm{mL}$. The solutions were filtered through a 0.45 $\mathrm{mm}$ membrane filter (Millipore) for further analysis. conditions

$$
\text { Instrumentation and chromatographic }
$$

The analyses were carried out using a
Shimadzu LC-10 liquid chromatograph equipped with quaternary pump (LC-10 AT), manual injection valve (Rheodyne), loop $20 \mu \mathrm{L}$, degasser (DGU-14A), thermostatted column compartment (CTO-10A), and a detector UV/vis (SPD-10A), controlled by CLASS VP Software. A Phenomenex ODS (C18) columm, $5 \mu \mathrm{m}, 250,0 \times 4,6 \mathrm{~mm}$, maintained at $30{ }^{\circ} \mathrm{C}$ was used in the chromatographic analysis. The separation was carried out in a gradient system, using as mobile phase a mixture of methanol:water. In time from 0 to $5 \mathrm{~min}$, methanol: water concentration ranged from 10:90 (v/v) to $70: 30(\mathrm{v} / \mathrm{v})$. In time from 5 to $12 \mathrm{~min}$ the concentration methanol:water remained at 70:30 (v/v), and at the time of 12 to $15 \mathrm{~min}$ the concentration of methanol:water ranged from $70: 30(\mathrm{v} / \mathrm{v})$ to $100 \%$ of methanol. The detection wavelength was $245 \mathrm{~nm}$ and flow rate of 1 $\mathrm{mL} / \mathrm{min}$, getting a run of $15 \mathrm{~min}$. The conditions were previously tested and optimized. The sample injection volume was $20 \mu \mathrm{L}$. Three determinations were carried out for each sample. The statistical analyses of the data were performed by Statistic 6.0 Software (Statsoft Inc., Tulsa, OK, USA).

\section{Validation}

After optimization of the chromatographic conditions established, the method was validated following the guidelines of the International Conference on Harmonization of Technical Requirements for the Registration of Pharmaceuticals for Human Use (ICH, 1996) checking linearity, precision, accuracy, limit of quantification and limit of detection.

\section{Linearity}

The linearity of the calibration curve for the $\beta$-ecdysone was established by the external standard method, based on five concentrations: $31.25,62.5,125$, 250 and $500 \mu \mathrm{g} / \mathrm{mL}$. Three determinations were carried out for each solution. The calibration curves were obtained by plotting the peak area of the $\beta$-ecdysone versus the concentration of the standard solutions. The statistical parameters of the calibration curve as slope, intercept, and correlation coefficient were calculated by linear regression analysis.

\section{Precision}

The repeatability of the method was evaluated for intra-day while the intermediate precision was determined for inter-days (on two non-consecutive days). The standard solutions were analyzed at three concentrations $(31.25,125$ and $500 \mu \mathrm{g} / \mathrm{mL}$ ). Three determinations were carried out for each solution. The relative standard deviation (R.S.D.\%) within the 
measurements of the concentrations of $\beta$-ecdysone was used to evaluate the repeatability and intermediate precision.

\section{Accuracy}

In order to evaluate the accuracy of this method, a recovery test was performed by adding standard solutions of $\beta$-ecdysone at the three concentration levels $(31.25,125$ and $500 \mu \mathrm{g} / \mathrm{mL}$ ) to crude extract of $P$. glomerata roots $(3000 \mu \mathrm{g} / \mathrm{mL})$ with a known content of this compound. Three determinations were carried out for each solution. The recovery was calculated as a percentage by subtracting the values obtained for the control matrix preparation from those samples that were prepared with the added standards, divided by the amount added and then multiplied by 100 .

\section{Limit of detection and quantification}

The Limit of Detection (LOD) and the Limit of Quantification (LOQ) were determined from the calibration curve of the standard $\beta$-ecdysone. The LOD and LOQ were measured based on a signal-to-noise ratio at about 3 and 10 , respectively.

\section{Results and Discussion}

\section{Validation}

Quantification of $\beta$-ecdysone was performed using the HPLC and a method with methanol and water, a solvent lower cost, different of Zimmer et al. (2006) which used acetonitrile and water in the mobile phase.

Results obtained in validation demonstrated an excellent linear relationship between the corresponding peak areas and the concentration of $\beta$-ecdysone in the range $31.25-500 \mu \mathrm{g} / \mathrm{mL}$ was achieved, as confirmed by the correlation coefficient of 0.9992 . The validating parameters of the calibration curve, including the linearity range, slope, intercepts, and correlation coefficients obtained by linear regression analysis are described in Table 1.

Table 1. Linearity parameters for the calibration curve of $\beta$-ecdysone.

\begin{tabular}{lcccc}
\hline Compound & $\begin{array}{c}\text { Linearity range } \\
(\mu \mathrm{g} / \mathrm{mL})\end{array}$ & Slope (a) & Intercept $(\mathrm{b})$ & $\left(\mathrm{r}^{2}\right)$ \\
\hline$\beta$-ecdysone & $31.25-500$ & 25847 & 218747 & 0.9992 \\
\hline
\end{tabular}

$\mathrm{r}^{2}$, determination coefficient.

The precision's method was evaluated in terms of repeatability and intermediate precision and showed RSD values lower than $2.2 \%$, whereas the accuracy, evaluated with recovery test by adding of $\beta$-ecdysone in known amounts to the crude extract of Pfaffia glomerata, showed a medium recovery of $97.28 \%$ with RSD below $4.27 \%$ for all analyzed concentrations, confirming the accuracy of the method.

The Limit of Detection is defined as the smallest quantity of $\beta$-ecdysone that is detectable in a sample, but not necessarily quantified under the stated experimental conditions; it was $1.88 \mu \mathrm{g} / \mathrm{mL}$. The Limit of Quantification is defined as the smallest quantity of compound in a sample that is quantifiable with acceptable precision and accuracy; this limit was 6.28 $\mu \mathrm{g} / \mathrm{mL}$.

\section{Analysis of roots}

Evaluation of chemical markers in herbal extracts allows the assessment of the quality of the material produced (Figueiredo et al., 2004). Quantification of $\beta$-ecdysone in HPLC is necessary to assess its presence in the extracts of roots of $P$. glomerata obtained through different types of extractive methods. The results are shown in Table 2.

The Soxhlet method proved to be best suited for the extraction of $\beta$-ecdysone from roots of $P$. glomerata. These heat-extraction methods assisted in the extraction, since, according to Daffre et al. (1975), the increased temperature increases the solubility of active substances, although the process is limited

Table 2. Quantification of $\beta$-ecdysone (\%) on HPLC according to the method and the extraction liquid with the results expressed as means and standard errors. Means expressed as \% of dry extract.

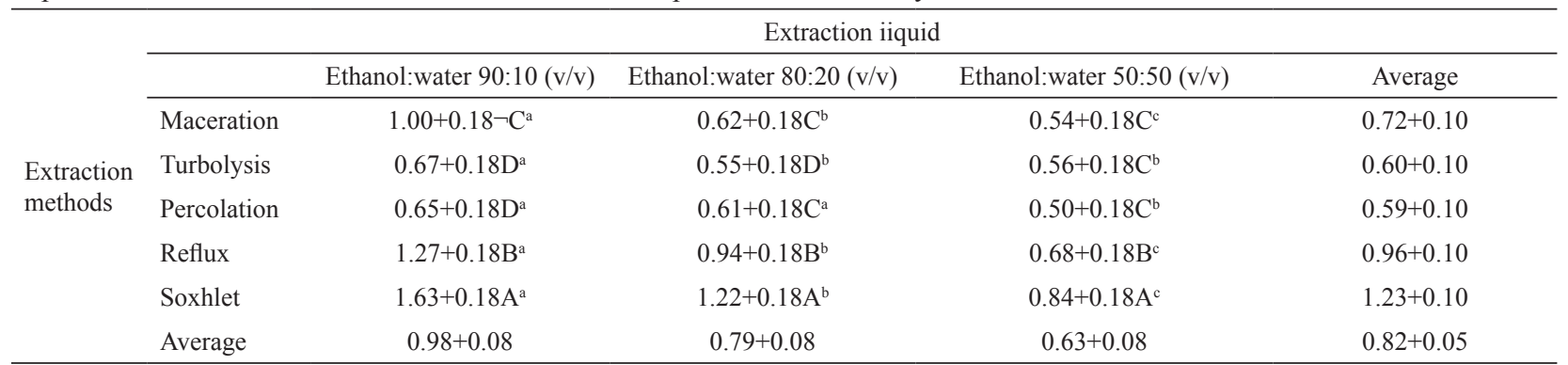

Means followed by same capital letters in column do not differ statistically (Tukey, $p>0.05$ ). Means followed by same small letters in row are not statistically different (Tukey, $p>0.05$ ). 
to thermostable substances. According to Vigo et al (2004), $\beta$-ecdysone is heat-resistant. Analysis of the extraction liquid revealed a statistical difference among the three concentrations, indicating that although the extractor ethanol:water 90:10 (v/v) gave a lower total yield of extract (data not shown), it resulted in a higher concentration of $\beta$-ecdysone. According to Celeghini et al (2007), the main objective of preparing an extraction solution is the production of larger quantities of the active substance of a drug.

Therefore, the Soxhlet method proved to be the most suitable for extracting $\beta$-ecdysone from roots of $P$. glomerata. This method, combined with the ethanol:water 90:10 (v/v) extraction liquid, yielded the highest concentration of $\beta$-ecdysone: $1.63 \%$ of the dry extract. This concentration of $\beta$-ecdysone is higher than that reported by Marques et al (2004), who carried out a psychopharmacological evaluation in rodents, and extracted $P$. glomerata with methanol using Soxhlet extraction for $4 \mathrm{~h}$; this extract was standardized at 1.07\% $\beta$-ecdysone. Another study by Marques et al (2002), used a standardized extract obtained by turbolysis and organic solvents in $0.96 \% \beta$-ecdysone in dry extract. These values are lower than those obtained in the present study.

The proposed Soxhlet technique using ethanol:water 90:10 (v/v) as extractor is interesting because it uses and re-uses a small amount of solvent, allowing exhaustive extraction of the drug in a relatively short time. Furthermore, the method uses an extraction liquid that is viable, easily accessible and recommended by the Brazilian Pharmacopoeia for the production of extracts from herbs. The use of heat in the process is essential, because it considerably increases the extraction of the active substance, as shown in the results.

\section{Analysis of stems and inflorescences}

Once the best conditions for extraction of $\beta$-ecdysone were defined, Soxhlet method and ethanol:water 90:10 (v/v), inflorescences and stems of the plant was extracted and used for comparison and determination of the chromatographic profile and quantification of chemical markers (Figure 1). In the analysis of extracts from stems and inflorescences, the substance identified as $\beta$-ecdysone, with a retention time of $9.3 \mathrm{~min}$, appeared as a major component in all extracts obtained from P. glomerata (Figure 1).

The assay of these extracts showed that $\beta$-ecdysone was not only present in large quantities, but in greater concentrations in the inflorescences and stems of P. glomerata than in the roots (Table 3). This result is consistent with those of Festucci-Buselli et al (2008), who cultivated different accessions of $P$. glomerata in vitro and examined the content of $\beta$-ecdysone in methanolic extract obtained from maceration of different parts of the plant (roots, stems, flowers and leaves). Plants grown in vitro, produced $\beta$-ecdysone which was found in all parts, with the highest concentration observed in the flowers.
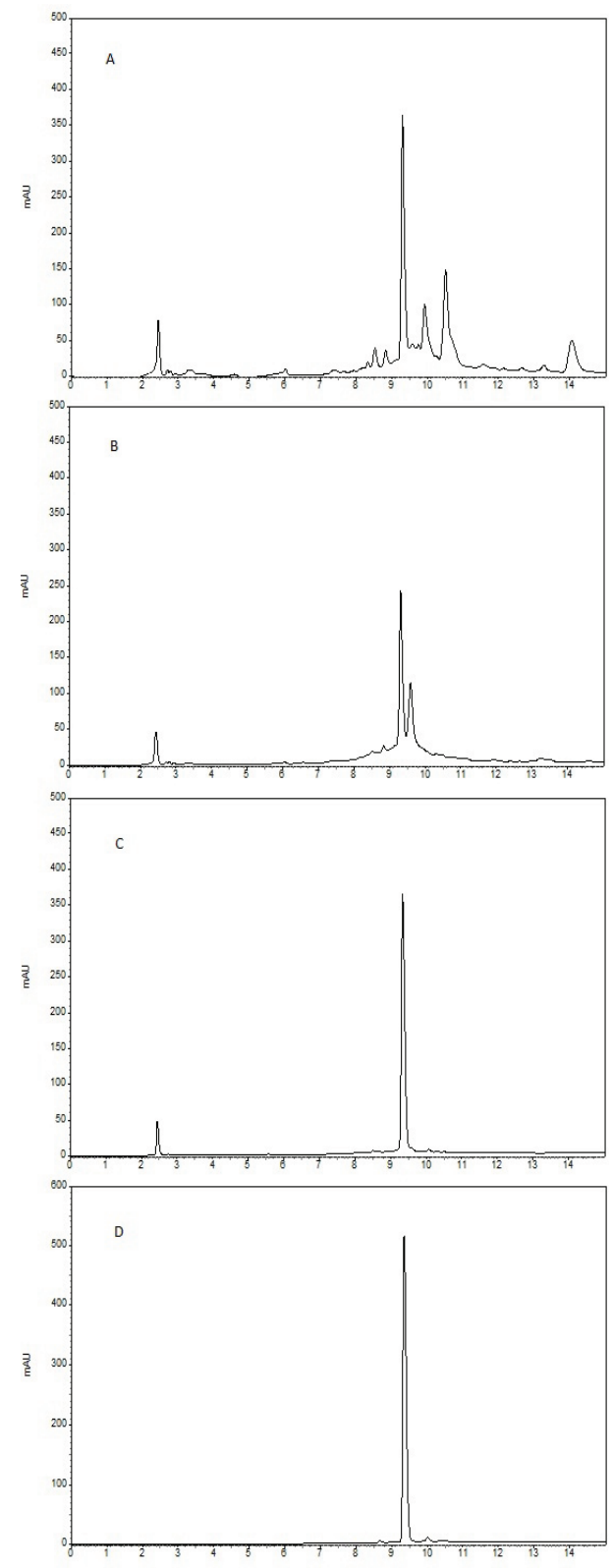

Figure 1. Chromatograms obtained by HPLC. Conditions: mobile phase: In time from 0 to $5 \mathrm{~min}$, methanol: water concentration ranged from 10:90 (v/v) to 70:30 (v/v). In time from 5 to $12 \mathrm{~min}$ the concentration methanol:water remained at 70:30 (v/v), and at the time of 12 to $15 \mathrm{~min}$ the concentration of methanol:water ranged from $70: 30(\mathrm{v} / \mathrm{v})$ to $100 \%$ of methanol. Flow: $1 \mathrm{~mL} / \mathrm{min}$, detection at $245 \mathrm{~nm}$ and oven temperature $30^{\circ} \mathrm{C}$. (A) extract from inflorescences of Pfaffia glomerata $3000 \mu \mathrm{g} / \mathrm{mL}$, (B) extract of the stems of $P$. glomerata $3000 \mu \mathrm{g} / \mathrm{mL}$, (C) the root extracts of $P$. glomerata $3000 \mu \mathrm{g} / \mathrm{mL}$, (D) standard of the $\beta$-ecdysone $250 \mu \mathrm{g} /$ $\mathrm{mL}$. Extracts obtained by extraction in Soxhlet extractor liquid ethanol:water 90:10 (v/v). 
Table 3. Results are expressed as mean and standard errors for yield of the extract and quantification of $\beta$-ecdysone HPLC in roots, stems and inflorescences of Pfaffia glomerata. Means expressed as \% of dry extract.

\begin{tabular}{lcc}
\hline \multicolumn{1}{c}{ Part used } & Extract yield $(\%)$ & $\beta$-ecdysone content $(\%)$ \\
\hline Roots & $24.2+0.48$ & $1.63+0.21$ \\
Stems & $11.0+0.48$ & $2.37+0.21$ \\
Inflorescences & $13.7+0.48$ & $3.06+0.21$ \\
\hline
\end{tabular}

The plants analyzed in this study, grown naturally in soil, also had a higher concentration of $\beta$-ecdysone in the inflorescences $(3.06 \%$ of the dry extract), followed by stems $(2.37 \%)$ and roots $(1.63 \%)$ (Table 3).

Thus, the best method for extraction the $P$. glomerata was Soxhlet method with ethanol:water $(90: 10 \mathrm{v} / \mathrm{v})$. The quantification of $\beta$-ecdysone in differents parts of plant showed that as roots, the stems and mainly the inflorescences can be used in the extraction of $\beta$-ecdysone, since this showed higher content this active substance when compared with others parts of plant. Currently, only the roots of $P$. glomerata are used for commercial extraction of $\beta$-ecdysone. However, in view of the continuing use of this substance by the pharmaceutical cosmetic industry, the presence of large quantities of $\beta$-ecdysone in the inflorescences opens the prospect of new sources of the active substance. In addition to the roots, the stems and mainly the inflorescences of this plant can be used, thus allowing more efficient utilization of the plant to obtain larger quantities of this chemical marker $\beta$-ecdysone.

\section{Acknowledgments}

This study was supported through grants from CNPq, FINEP, PRONEX/Fundação Araucária and Programa de Pós-graduação em Ciências Farmacêuticas da Universidade Estadual de Maringá.

\section{References}

Celeghini RMS, Yariwake JH, Lanças FM 2007. Otimização das condições de extração hidroalcoólica das furanocumarinas de Dorstenia brasiliensis Lam. por maceração com ultra-som e análise quantitativa por CLAE/UV e fluorescência. Rev Bras Pl med 9: 61-66.

Correa Junior C, Ming LC, Cortez DAG 2008. Sazonalidade na produção de raízes e teor de $\beta$-ecdisona em acessos de fáfia. Hortic Bras 26: 393-397.

Cortez DAG, Truiti MCT, Cortez LER 1998. Ginseng Brasileiro: revisão bibliográfica. Arq. Cienc Saúde Unipar 2: 299306.

Daffre C, Cimino JS, Helou JH 1975. Farmacotécnica. São Paulo: Artpress.
De-Paris F, Neves G, Salgueiro JB, Quecedo J, Izquierdo I, Rates SMK 2000. Psychopharmacological screening of Pfaffia glomerata Spreng (Amaranthaceae) in rodents. J Ethnopharmacol 73: 261-269.

Farmacopéia Brasileira, 4a ed., 1988. São Paulo, Atheneu. Festucci-Buselli RA, Contim LAS, Barbosa LCA, Stuart JJ, Vieira RF, Otoni WC 2008. Level and distribuition of 20-hydroxyecdysone during Pfaffia glomerata development. Braz J Plant Physiol 20: 305-311.

Figueiredo LS, Teixeira SL, Freitas SP, Vieira IJC, Artins ER 2004. Comportamento de acessos de Pfaffia glomerata nas condições de campos de Goytacazez-RJ. Rev Bras Pl Med 7: 67-72.

Flores R, Nicoloso FT, Brondani D, Maldaner J, Cezarotto V, Giacomelli SR 2009. Extração de ecdisterona em raízes de ginseng brasileiro. Cienc Rural 39: 12221226.

Freitas CS, Baggio CH, Silva-Santos JE, Rieck L, Santos CAM, Corrêa Junior C, Ming LC, Cortez D A G, Marques MCA 2004. Involvement of nitric oxide in the gastroprotective effects of an aqueous extract of Pfaffia glomerata (Spreng) Pedersen, Amaranthaceae, in rats. Life Sci 74: 1167-1179.

Gomes ACMM, Nicole M, Mattos JK, Pereira SIV, Pereira P, Silva DB, Vieira R, Capdeville G, Moita AW, Carneiro RMDG 2010. Concentration of $\beta$-ecydisone (20E) in susceptible and resistant accessions of Pfaffia glomerata infected with Meloidogyne incognita and histological characterization of resistance. Nematology 12: 701-709.

Gosmann G, Gattuso S, Gattuso M, Fenner R, Pacheco EF, Ferraz A, Savi LA, Barardi CRM, Simões CMO, Sortino M, Zacchino S, Gnerre C, Testa B, Rates SMK 2003. Botanical (morphological, micrographic), chemical and pharmacological characteristics of Pfaffia species (Amaranthaceae) native to South Brazil. Braz J Pharm Sci 39: 141-147.

Guerreiro CPV 2006. Análise de crescimento, curva de absorção de macronutrientes ( $N$, P e K) e teor de $\beta$ ecdisona em fáfia (Pfaffia glomerata (Spreng) Pederson): em função de adubação orgânica. Botucatu, 124p. Dissertação de Mestrado. Faculdade de Ciências Agronômicas, Universidade Estadual Paulista.

International Conference on Harmonization of Technical Requirements for the Registration of Pharmaceuticals for Human Use (ICH) Q2 (R1). 1996. Validation of analytical procedures.

Marques LC, Danucalov MA, Torres F, Galduroz JC, Carlini ELA, Silva AC 2002. Estudo clínico duplo-cego de extrato padronizado (BNT-08) das raízes de Pfaffia glomerata (Spreng.) Pedersen: avaliação do efeito tônico em atividade física. Rev Bras Farmacogn 12: 44-47.

Marques LC, Galvão SMP, Espinola E, Dias RF, Mattei R, Oliveira MGM, Carlini ELA 2004. Psychophamacological assesment of Pfaffia glomerata roots (extract BNT-08) in rodents. Phytother Res 18: 566-572. 
Montanari Junior I 2005. Avaliação de genótipos de Pfaffia glomerata (Spreng) Pederson visando seu cultivo comercial. Campinas, 63p. Dissertação de Mestrado, Instituto Agronômico de Campinas.

Neto AG, Costa JMLC, Belati CC, Vinholis AHC, Possebom LS, Silva Filho AA, Cunha WR, Carvalho JCT, Bastos JK, Silva MLA 2005. Analgesic and anti-inflammatory activity of a crude root extract of Pfaffia glomerata (Spreng) Pedersen. J Ethnopharmacol 96: 87-91.

Nicoloso FT, Fortunato RP, Fogaça MAF 1999. Influência da posição da estaca no ramo sobre enraizamento de Pfaffia glomerata (Spreng) Pedersen em dois substratos. Cienc Rural 29: 277-283.

Oliveira F, Akisue K, Akisue MK 1998. Farmacognosia, São Paulo: Atheneu.

Otofuji GM 2005. Vias envolvidas no mecanismo de ação do efeito gastroprotetor das raizes de Pfaffia glomerata (Spreng) Pederson. Curitiba, 151p. Dissertação de Mestrado. Universidade Federal do Paraná.

Sanches NR, Galleto R, Oliveira CE, Bazotte RB, Cortez DAG 2001. Avaliação do potencial anti-hiperglicemiante da Pfaffia glomerata (Spreng) Pederson (Amaranthaceae). Acta Scientarium 23: 613-617.

Shiobara Y, Inoue S, Kato K, Yukari N, Nishiguchi YO, Nishimoto N, Oliveira F, Akisue G, Akisue MK, Hashimoto G 1993. A nortripernoid, triterpenoids and ecdysteroids from
Pfaffia glomerata. Phytochemistry 32: 1527-1530.

Souza DJFS, Alves KZ, Da Silva Jacques DS, Silva e Souza PVS, Carvalho MG, Freire RB, Ferreira DT, Freire MFI 2005. Free radical scavenging activity of Pfaffia glomerata (Spreng) Perdersen (Amaranthaceae). Indian J Pharmacol 37: 174-78.

Taniguchi SF, Bersani-Amado CA, Sudo LS, Assef SMC, Oga, S 1997. Effetc of Pfaffia iresinoides on the experimental inflammatory process in rats. Phytother Res 11: 568-571.

Vigo CLS, Narita E, Marques LC 2004. Influências da variação sazonal e tipos de secagem nas características da droga vegetal-raízes de Pfaffia glomerata (Spreng.) Pedersen (Amaranthaceae). Rev Bras Farmacogn 14: 137-144.

Zimmer AR, Bruxel F, Bassani VL, Gosmann G 2006. HPLC method for the determination of ecdysterone in extractive solution from Pfaffia glomerata. J Pharm Biomed Anal 40: 450-453.

\section{*Correspondence}

Diógenes A. G. Cortez

Laboratório de Pesquisa em Produtos Naturais e Biotecnologia, Universidade Estadual de Maringá, Brazil.

dagcortez@uem.br

Tel.: +554430115248 